\title{
Results of creation of technical means for growing crops on resources-saving techno-logies
}

Adamchuk V. ${ }^{1}$, Grytsyshyn M. ${ }^{2}$, Nasonov V. ${ }^{3}$, Ratushnyi V. ${ }^{4}$

${ }^{1-4}$ NSC "Institute of mechanization and use of electric power in agriculture», Vokzalna Str., 11, Glevakha, Vasylkiv region, Kyiv oblast, 08631, Ukraine; e-mail: '1vvadamchuk@gmail.com,

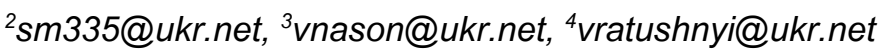

The purpose. To gain new scientific knowledge and to create on their basis highly effective complexes of technical means for growing crops on resources-saving technologies. Methods. With the use of laws of mechanics mathematical models of interaction of tools of machines with technological materials and soil are gained; their basic rules are experimentally tested, imitating models of working processes are developed; assessment of basic parameters of technical means is made during departmental and state warranty tests in the Institute on the basis standard techniques. Results. New theory of interaction of tools with technological materials of technical means is developed for agrochemical maintenance of agroindustrial production; bases of the theory of distribution of technological materials on the surface of field in view of conditions of accomplishment of production operations are created; basic new methodology of formation of approaches to substantiation of rational uniformity of seeding in view of zones of plant nutrition is developed; new regularity of work of wide web pressure-pneumatic centralized systems of sowing complexes and seeders are determined; new regularity of dynamics of traffic of machine-tractor assemblies generated with the use of one-operational and multioperational machines is gained. With the use of these results the highly effective complex of technical means which have successfully passed state warranty tests is created, and their production by the domestic factories of agricultural engineering industry is mastered. Conclusions. On the basis of the gained new knowledge highly effective technical means which are characterized by high technical-andeconomic indexes are developed, namely: their productivity not below, than at the best world analogues, and in separate components it is above in 1,5-2 times, these means provide decrease of over-all specific power inputs on $20-30 \%$ at the price of machines below in 1,5-2,3 times. Implementation in production of these complexes has already given economic benefit nearby 2,5 billion hrn.

Key words: theory, development, test, tech-no-logy, technical means, resource saving, efficiency.

\section{https://doi.org/10.31073/agrovisnyk201811-19 \\ INTRODUCTION}

The development of domestic agricultural production depends on the competitiveness of its products, which is largely determined by the specific energy consumption and costs of technological materials for its production and effective planning of crop production projects [1]. It should be noted that the specific energy consumption and costs of technological materials are influenced not only by the technologies used to grow crops but also by technical means, which carry out the related technological operations. Therefore, Ukrainian farmers need to make extensive use of energy- saving resource technologies, and for this they need high-performance hardware complexes. This can be confirmed by the well-known conclusion of Academician V. R. Williams:"No technology would be perfect in the agriculture system, but it would remain an unfulfilled dream if it were not provided with the same perfect technique."

Thus, for the implementation of energy- saving resource technologies in growing cereals and other crops, agro-industrial production should be provided with the necessary high-efficient complexes of technical means for performing technological operations, the main of which are: fertilization, soil preparation, sowing and care of crops. Requirements for such technical means by the authors are formed in their work [2].

The numerical range of technical means is now supplied by foreign manufacturers of agricultural machinery. But updates tractor fleet at the domestic agricultural machinery imported financially affordable 
difficult due to their poor credit. In addition, it should be noted that the food security of the country is determined not only by the use in agricultural production of varieties, hybrids of plants and breeds of domestic breeding animals, but also by the corresponding technical and technological support. Otherwise, domestic agricultural production will be a hostage to all political and economic conflicts in which the interests of our state will be involved. The state that produces grain will be dependent on the countries supplying it with technical equipment for the production of this grain and spare parts for machinery.

In connection with the described, development and implementation of highly effective complexes of technical means for growing cereals and other crops for

energy- saving resource technologies will be relevant for agro-industrial production in Ukraine.

NSC "IAEE" has a considerable experience in the development of technical means for the use of solid mineral fertilizers. Together with the machine-building enterprises in the previous period were created machines for fertilizer dispensing MVD-0.5, MVD-900, STT-10, 1-RMG-4A, MVU-5 SPRO, PSH-21; technical means for fertilizing into the soil of AVM-8, UGK-4,2 and loading loaders of seeders BZU-5, BZU-6. Some of the above-mentioned technical means and by this time are made by machine-building enterprises, and some have been modernized. They were developed and put together with the enterprises of agricultural machinery for the production of a complex of single-action tillage implements for tractors of different capacities, for example: PN-5-40, PN-6-40, PN-2-30, PN-3-30, PN plows -4-30, PNYA 4-40, PNYA 6-40; wide-level disc tiller LD-8, LD-11, LD-14; Coupling harrows ZG-10, ZG-16, ZG18, ZG-22; cultivators KPSN-4, KPSP-8, heavy disk harrows BDV-6, etc.

The purpose of the research - is to increase the efficiency of growing of cereals and other crops due to energy, resource-saving technologies and high-efficiency complexes of machines developed on the basis of new scientific knowledge.

\section{MATERIALS AND METHODS}

Using the laws of mechanics, have mathematical models been obtained for the interaction of working bodies of machines with technological materials and soil; Experimentally checked their basic position, developed simulation models of work processes; with the use of standard techniques, the main indicators of the appointment of technical means in the process of conducting departmental and state entrance examinations in the UkrNIIPVT named by L. Pogorilyi.

\section{RESULTS AND DISCUSSION}

Theoretical and experimental research was conducted, on the basis of which a new theory of interaction of working organics with fertilizers was developed, the main provisions of which are given in the works [3, 4]. This made it possible to create machines that make fertilizers with a working width up to $36 \mathrm{~m}$, which, depending on the type of mineral fertilizers, increases productivity by 1.5-2.0 times and reduces the specific waste of fuel. In addition, the bases of modeling of the distribution process by fertilizer spreaders on the surface of the soil have been developed, which allow to determine with high accuracy the performance indicators of machines at the stage of their design. This approach provides a cheaper process of creating a new technology and there are no analogues in the world.

The above results were used in the creation of new technical means that ensure fertilization with unevenness of up to $20 \%$, in particular,

machines for mineral fertilizers RN-0,8; RN-1 (OOO "UkrSilGospmas"); MVDT-0,5, MRD-5 (Fig. 1); MVD-9, MVD-9A (SE "Agromash" NSC "IAEE"), MRD-4 (OJSC "Kovelsilmash").

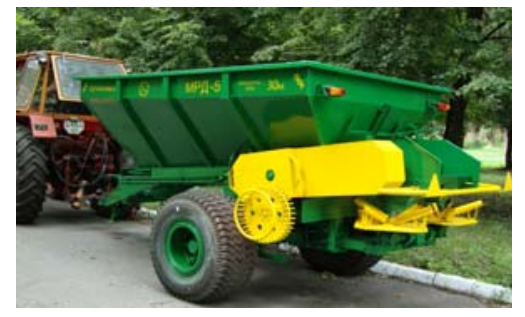

Fig. 1. The machine for dispersion of mineral fertilizers MRD-5 
The economic efficiency of soil cultivation is also relevant to agriculture, since this technological operation is one of the most energy-intensive and labor-intensive. Depending on the technology, in the structure of direct operating costs for performing soil tillage operations, up to $40 \%$ of direct operating costs, up to $41 \%$ of energy consumption and up to $25 \%$ of labor costs accounted for. According to the modern classification, four main systems of cultivating the soil are distinguished: traditional (on the basis of field cultivation - plowing), minimal (on the basis of non-polar surface and shallow loosening), preserved (on the basis of deep loosening) and "zero" (seed in unprocessed forward soil )

Modern development of soil tillage systems in the direction of energy saving has led to wider application, along with the traditional and minimal maintenance of the soil (Mini-Till) of preserved cultivation, strip making (Strip-Till) and zero (No-Till). Expansion of the arsenal of soil cultivation technologies for the purpose of energy saving rescue resulted in the tendencies of the development of constructions of soil cultivating machines, namely, multioperational (combined) machines and multifunctional (universal) aggregates that would be carried out in one pass under different soil and climatic conditions several operations, minimizing time, fuel, fertilizer and negative effects on the soil.

Following the established tendencies, scientists NSC "IAEE" directed research on the creation of new technical means for the mechanization of soil cultivation in accordance with the requirements of modern technology. At the same time, they moved in several ways, in particular: expanded the functionality of previously created and well-worked designs of single-use machines (disc tiller, disk harrows, cultivators); developed new versatile-combined machines and units for minimal, preserved and bandage soil cultivation.

One of the mentioned directions was the creation of domestic steam cultivators, which are intended for pre-planting of soil cultivation and care of pairs. In one pass they provide trimming and loosening of soil to the depth of seeding, weeding weeds, leveling and compacting the seed layer of soil. That is, modern cultivators are multifunctional combined soil cultivators. Steam cultivators of the "K" series (K-4,3; K-7,3; $\mathrm{K}-7,8$; K-8,3; K-9,3; K-11) have been developed with the participation of NSC "IAEE", production which mastered LLC "Krasnyanske", SP" Agromash " and cultivators POLARIS 4, 8 POLARIS, POLARIS 12 JSC" Elvorti. "When creating the cultivators of the specified series, the aim was to increase their functional capabilities, to ensure quality soil preparation to sow crops in fields with a large number of roses and plant residues in the upper layer of soil (minimal and canning technologies).

In comparison with steam cultivators, heavy cultivators are more versatile in terms of types and conditions of soil cultivation. They are able, like steam cultivators, to perform pre-planting soil tillage on different backgrounds and to care for pairs. Heavy cultivators are also used for basic, shallow tillage till 16 $\mathrm{cm}$ under the Mini-Till system. In the case of the equipment of these machines, they can be used by narrow nursers for a deeper preserved soil cultivation (up to $25 \mathrm{~cm}$ ). They often serve as a base for the creation of soil tillage machines. Despite the fact that these machines are more complex in design, more metal-intensive, today they are in demand from agricultural producers thanks, first of all, to their multifunctionality.

The production of a series of heavy cultivators ALSOR (ALSOR 7,5, ALSOR 10) was mastered by PJSC "Elverti". They are intended for continuous tillage of soil on pure and sternous backgrounds to a depth of $3.0-18 \mathrm{~cm}$ with simultaneous harrowing, leveling and laying of soil with a working speed up to $10 \mathrm{~km} / \mathrm{h}$.

The production series of heavy cultivators KV-3 and KV-4, mounted on the all-purpose design of the all-purpose design and the KV-6 trailer type, was mastered by LLC "Krasnyanske" JV "Agromash". On them in three rows are located working bodies in the form of wide (for cultivating the soil to a depth of 16 $\mathrm{cm}$ ) or narrow paws (for cultivating soil to a depth of $25 \mathrm{~cm}$ ), mounted on elastic twisted racks.

In addition, it was found that in order to improve soil cultivation in fields with a large number of plant remains, intensive crushing and wrapping of siderates, it is expedient to increase the number of disk working bodies per unit of trapping width by 1.3-1.4 times. Based on this, the NSC "IAEE" together with LLC "Krasnyanske" JV" Agromash" has created D-6, D-8 and D-10 discs that provide a depth of tillage of 
$12 \mathrm{~cm}$. PJSC "Elvorti" used this approach when creating discs ANTARES collection (ANTARES $3 \times 4$, ANTARES $4 \times 4$, ANTARES $6 \times 4$, ANTARES $8 \times 4$ ), which provide a depth of tillage of $18 \mathrm{~cm}$.

In domestic agricultural production, heavy disk harrows are in high demand due to the fact that they are simple in design, reliable and versatile in terms of application conditions. In Ukraine, in the early 90's, the creation of heavy disk drives was initiated by a group of scientists of our institute led by academician NAAN Gukova Ya.S. At the present stage, the Institute has developed new models, the production of which has been mastered by machine-building plants. Leader in the production of competitive structures are heavy harrows of LLC "Krasnyanske" JV" Agromash ". For Ukrainian farms and farms of the near abroad, the company produces a wide range of such machines for tractors of various capacities, which includes the brands: BDVP-2,5; BDVP - 3.0; BDVP - 3,6; SDDS - 3.8; BDVP - 4,2; BDVP - 5,5; SDDS 6.3 and SDDS - 7.2. These harrow discs by using increased to $710 \mathrm{~mm}$ diameter provide the depth of tillage to $22 \mathrm{~cm}$ at operating speeds up to $12 \mathrm{~km} / \mathrm{h}$.

In addition to heavy disk harrows, discs and cultivators in the system of minimal tillage, light disk harrows are widely used, which have the same design as heavy, but differ only in smaller diameter of disks, which is $490 \mathrm{~mm}$, and laminated frames. Their purpose is to peel the soil after harvesting the crops. With a sufficient amount of moisture in the soil they are also used for pre-planting. Two brands of such harrows: BDLP-4 and BDLP-8 have been developed and serially manufactured in LLC "Krasnyanske" JV "Agromash". They provide a depth of cultivation of soil within 4-14 cm.

Preparation of soil for the sowing of small-flowered crops and other plants whose seeds are earned in the soil on a small depth (rape, herbs, etc.), steam and heavy cultivators in one pass do not provide the appropriate quality soil cultivation. We have to make several passes, resulting in increased costs and drying soil. Therefore, a special type of combined multi-operation machines is developed - compactors, which, in one pass, provide the necessary quality of soil preparation to sow the specified crops. They are used predominantly after plowing or other preliminary soil cultivation with a small amount of plant residues on the surface. In developing the new generation of compactors AK-6 and AK-7, the authors based on their own experience in the creation and operation of such machines, which were developed in the previous stage (for example, KA-4,4; AKG-3,6; AKG-4; AKG-6, AMO -7.2) and take into account the developments leading European companies in terms of layout schemes and working bodies. Created compactors provide high-quality cultivation to a depth of 2-10 $\mathrm{cm}$. With the advent of powerful tractors in farms a demand for more efficient cars such purpose. In connection with this circumstance, the authors developed a new compactor AK-10 with a width of $10 \mathrm{~m}$ (Figure 2).

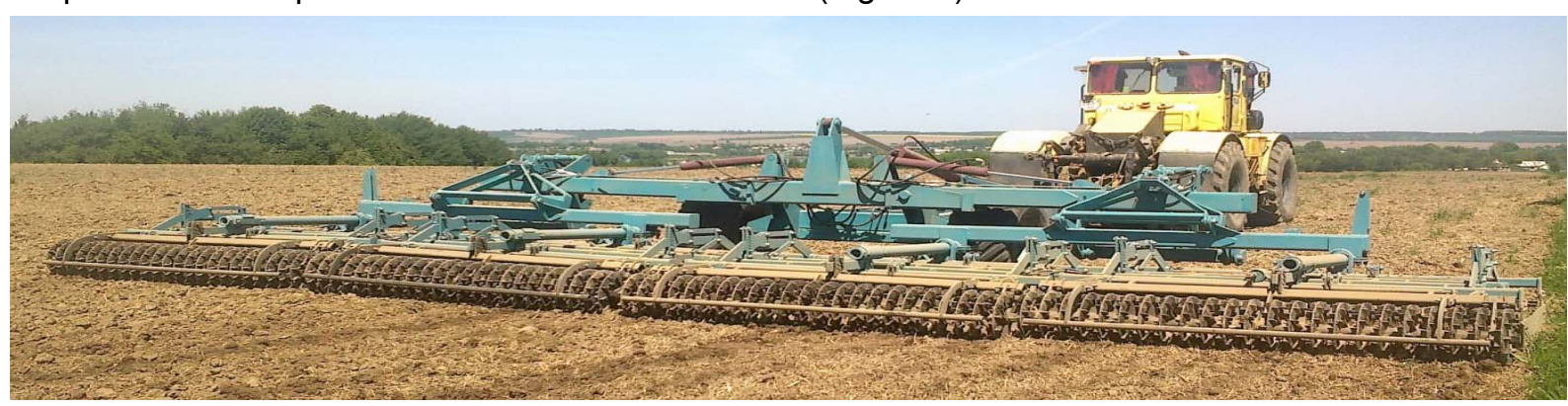

Fig. 2. Compactor AK-10 in working condition

For the deep loosening of the soil (up to $40 \mathrm{~cm}$ ), a chisel device was developed in the system of preserved cultivation. They are equipped with original asymmetric working bodies. Due to the single-row frontal arrangement of working bodies with an adjustable distance between them $(600-850 \mathrm{~mm})$ during movement of the instrument a ground wave is formed with continuous lifting and lowering of the treated layer. This causes the appearance of a plurality of cracks and microcracks in the soil. Chisels deeply spreaders are used mainly for grassland tillage.

The more prepared for the sowing background provide combined disco-chisel implements, so they can be used not only for conservative cultivation of soil for autumn ploughing, but also for cultivating it under winter crops. They are well developing soil after corn, rape and sunflower. They are well developing soil after corn, rape and sunflower. NSC "IAEE" together with LLC "Krasnyanskyi" JV " Agromash "created 
disco-chysel harrows BDVP-3,0-0,1; BDVP-4,2-0,1; BDCH-5; BDCH-5; BDCH-6; and BDCH-7, in which the wheels provide a depth of tillage of $22 \mathrm{~cm}$, and chisels up to $40 \mathrm{~cm}$.

The agro-technical and economic attractiveness of the disco-chyzel boron is high and increases when they are additionally equipped with equipment for the introduction of liquid fertilizers and biodestructors. Such equipment installed by request of consumers to these machines (Fig. 3). For preserved cultivation, it allows to gradually introduce into the soil nitrogen or complex fertilizers and superficially apply biodestructors on plant residues to intensify their decomposition after wrapping in the soil. Local fertilization allows to achieve the planned yields for less than $30-35 \%$ of doses compared with their application to the soil surface. In addition, the use of mineral fertilizers in liquid form reduces the energy consumption of their production compared with the solid form.

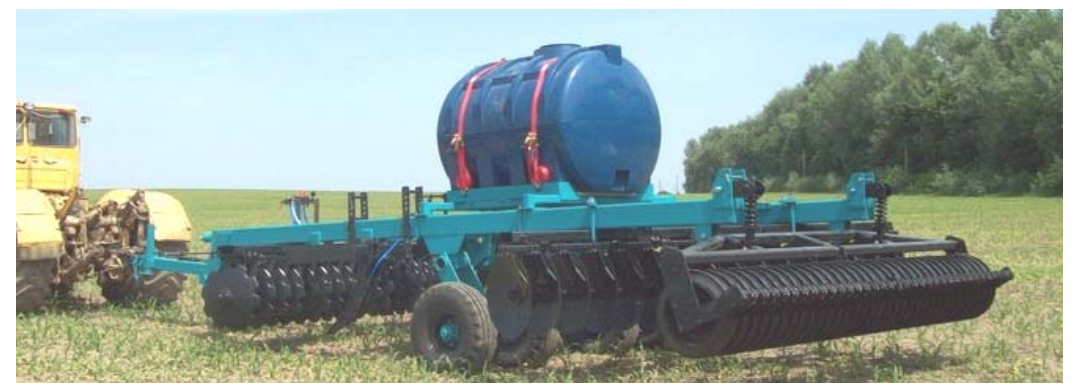

Fig. 3. Disco- chisel harrow BDVP-4,2-01 with equipment for the introduction of liquid fertilizers and biodestructors

Strip -Till is considered a kind of preserved cultivation. This is a compromise between intense, continuous loosening of the soil and zero work, combining the benefits of conservative cultivation and the No-Till system. Simultaneously with the strip treatment of the soil, it is possible to introduce several types of to-beams to feed the plants throughout their period of vegetation. The technology should include the following: reduction of the number of passes of aggregates in the field to $1-2$; reduction of fuel consumption up to $70 \%$ in comparison with tradi tional technology; reduction to $30 \%$ of the amount of fertilizer; increasing labor costs and increasing the service life of machinery.

Solving the problem of ensuring domestic agricultural production by modern technology, scientists by NSC "IAEE" have developed unified aggregates for the sand cultivation of soil ASOG-6 and ASOG-8 (Figure 4), the production of which was mastered LLC "Krasnyanske JV" Agromash ".

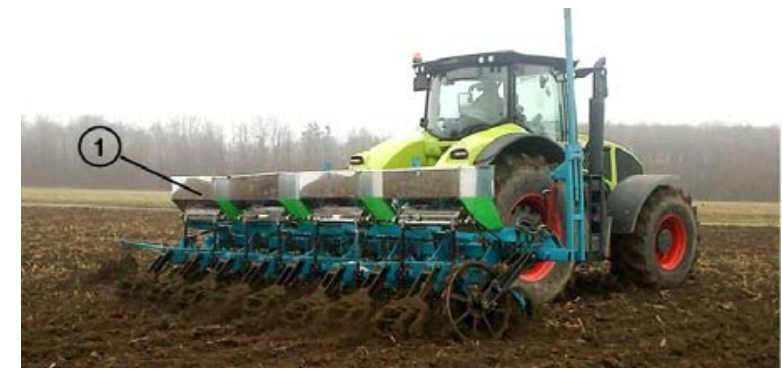

Fig. 4. The unit band tillage ASOG-8 with equipment for mineral fertilizers

It is well-known that the increase in the efficiency of the AIT is achieved at the expense of the technical and operational parameters of energy resources and technological modules. The use of combined multi-operation and multifunctional technological modules in a unit with heavy-duty tractors provides an increase in the productivity of machine-tools in 1,8-2,0 times and a reduction of specific fuel consumption by $20-40 \%$ compared to single-use machines and implements. New regularities of dynamics of motion of multioperational aggregates for soil cultivation and multifunctional aggregates for performing soil cultivation, fertilizer application, grain sowing and other crops $[6,7,8]$ have been established. The presence of such laws for the first time in world practice allowed at the stage of designing machines to rationally choose the parameters of their work, taking into account the conditions of operation, which contributed to a significant increase in the stability of movement of their working bodies and controllability of multioperational and multifunctional aggregates in general. This approach allows us to form 
multifunctional aggregates based on single-operation and multi-operation machines (Figure 5). This reduces operating costs by reducing unit costs and increasing the annual load of machines.

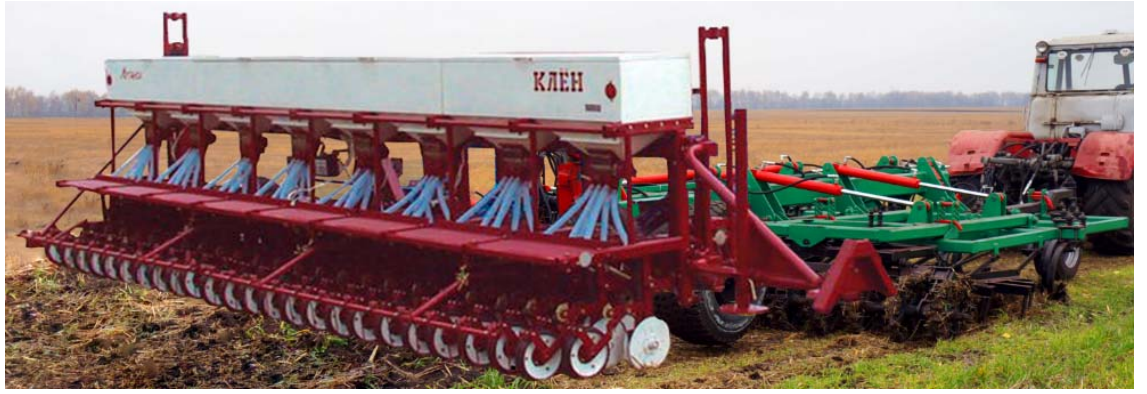

Fig. 5. Soil-cultivating and sowing unit (AKG-4,5 + KLEN-4,5)

A fundamentally new methodology of forming approaches to the substantiation of technical solutions that provide for a more rational distribution of seeds and fertilizers, taking into account the zones of plant nutrition, has made it possible for the first time in the world to give a quantitative assessment of the effectiveness of different methods of sowing without laying field experiments. In particular, it has been found that the most effective is a groundbreaking-scattering method of sowing [5]. In addition, new regularities of the operation of wide-reaching centralized pneumatic systems of seed systems, seeders and their wrappers have been established, which at the stage of designing broad-hanging seeding equipment has become the theoretical basis for substantiating rational parameters and operating modes of these systems.

Using the indicated results, the domestic leader in the production of seeding equipment at PJSC "Elvorti" has mastered the production of complexes: ALCOR 7.5 and ALCOR 10 with a working width of capture of 7.5 and $10 \mathrm{~m}$ respectively (Fig. 6). They are intended for the sowing of grain, leguminous and other crops, close to the size of the seeds and the norms of sowing to cereals, with traditional and minimal or preserved tillage tillage of the soil. On light soils, direct sowing can be done without preliminary soil cultivation. Carry out in one pass a continuous pre-planting cultivation on depth of sowing and one hundred percent cutting of weeds, a striped submerged spreading seed and seed doses of mineral fertilizers.

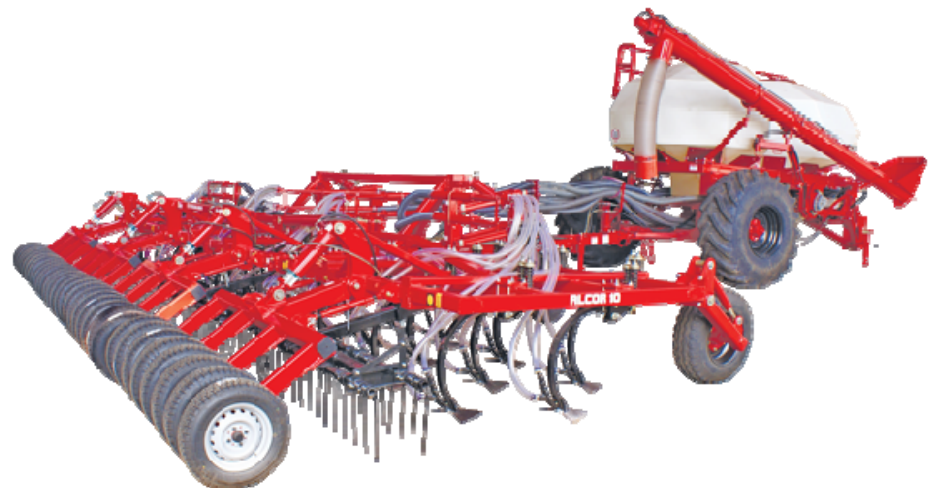

Fig. 6. Sowing complex ALCOR 10

A new way of covering seeds of crops in the course of its treatment with a film of a working liquid of means of protection without mechanical damage to the seed itself has been developed. The regularities of the process of seed processing are investigated theoretically and the rational values of the parameters and modes of the work of the purifier are determined [9,10,11]. ] The production of a purifier on request of agricultural commodity producers is conducted by SE "Agromash" of NSC "IAEE" (Fig. 7). The use of a protectant provides a $10 \%$ reduction in the specific consumption of preparations. The highest economic effect is achieved when treating seeds, which is particularly susceptible to mechanical injury (eg, soya, sunflower, etc.). 


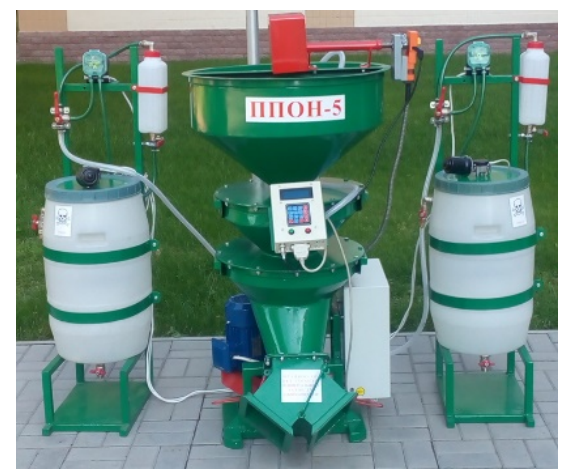

Fig. 8. Protectant by seeds PPON-5

In modern conditions, provision of high yields of agricultural crops is possible provided that there are modern machines for introducing chemical means of plants - spraying machines. Works in this direction are conducted on a scientific basis, which in previous periods was initiated by a corresponding member of the Maslo I. P. and candidate of technical sciences Baranovsky O. S. In particular, the system of stabilization of the horizontal position of the spray rod rod was developed, the system of separate feed in the rod of the preparation and water without preliminary mixing was developed, and the expediency of transition to the import element base was developed, which allowed to achieve the competitiveness of domestic sprayers in a very short time. NSC "IAEE" developed the sprayers OSSH-2500 and Orlan-24, the production of which was mastered by OJSC "Fregat Plant" and "Ukrsilgospmash", respectively. Together with the NUBiP developed by a sprayer with forced sedimentation of OPG-2000 droplets was developed. air stream in wind conditions are given in [5].

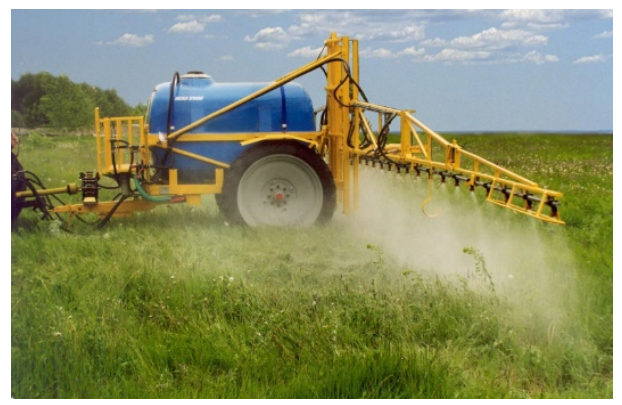

Fig. 9. Sprayer OSSH-2500

The results of the scientific development of the Institute for the creation of sprayers were used by PJSC "Boguslavskaya agricultural machinery", which now manufactures competitive sprayers KRONOS2000-18; KRONOS-3000-21,5; TITAN-3000-24; ATLANT-3000-28; ATLANT - 4200; which provide a working width of capture from 18 to $36 \mathrm{~m}$. Sprayers STORM-2000-18 and STORM-3000-18 (fig. 10) are equipped with pneumatic systems of droplet deposition, which improves the quality of crop processing by means of protection, allows to work in windy weather. With the help of air streams, small drops quickly penetrate the crop and settle on the leaves. The system provides for the creation of small drops (up to 200 microns) that cover a larger surface. This feature allows you to reduce the cost of preparations by $30 \%$.

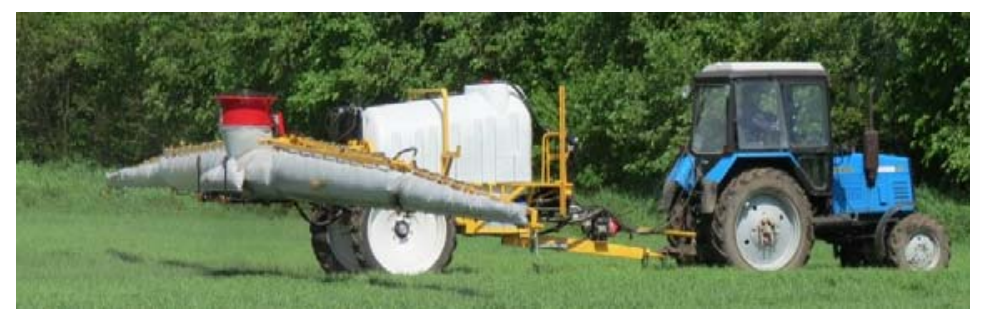

Fig. 10. Sprayer STORM-3000-18, equipped with a pneumatic system of precipitation of droplets

Particular attention deserves the work on the creation of self-propelled sprayers IBIS-3000 and MAF4200 , which production was mastered by PJSC "Boguslavskaya agricultural machinery". They have a 
clearance of $1800 \mathrm{~mm}$ and are accordingly equipped with rods with a width of capture of 24 or $28 \mathrm{~m}$ and 32 or $36 \mathrm{~m}$.

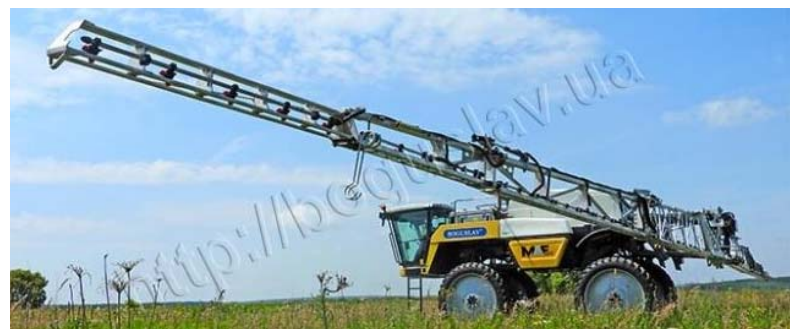

Fig.11. Self-propelled MAF-4200 sprayer

The mentioned technical facilities and others that were created with the participation of the institute, successfully passed departmental, and then state admission tests in the UkrNIMPVT named by L. Pogorilogo and put into production, which made them in the amount of more than 28 thousand units. They are characterized by high technical and economic indicators, namely: productivity is not lower than in the best world analogues, and at separate technical means it exceeds 1,5-2,0 times, provide reduction of total specific energy consumption by $20-30 \%$, at the price, which is $1.5-2.3$ times lower than foreign analogues. The introduction of the production of these complexes has had an economic effect, which is about 2.5 milliard UAH. The named enterprises of agricultural machine-building $15-30 \%$ of its products are exported abroad, including to EU countries, which delivered 5527 pieces of equipment.

In general, the results of the work have contributed to the growth of the influence of Ukrainian enterprises of agricultural machinery on the domestic market of machinery for agro-industrial production. This was especially apparent in the segment of soil cultivation and seeding technology. Starting from 2013, the volume of procurement of soil-cultivating and sowing machinery of foreign production is decreasing, and, at the same time, the volume of procurement of domestic production equipment is increasing, which now has more than $70 \%$ of the domestic market and more than $50 \%$ for agricultural machinery (Fig. 12)

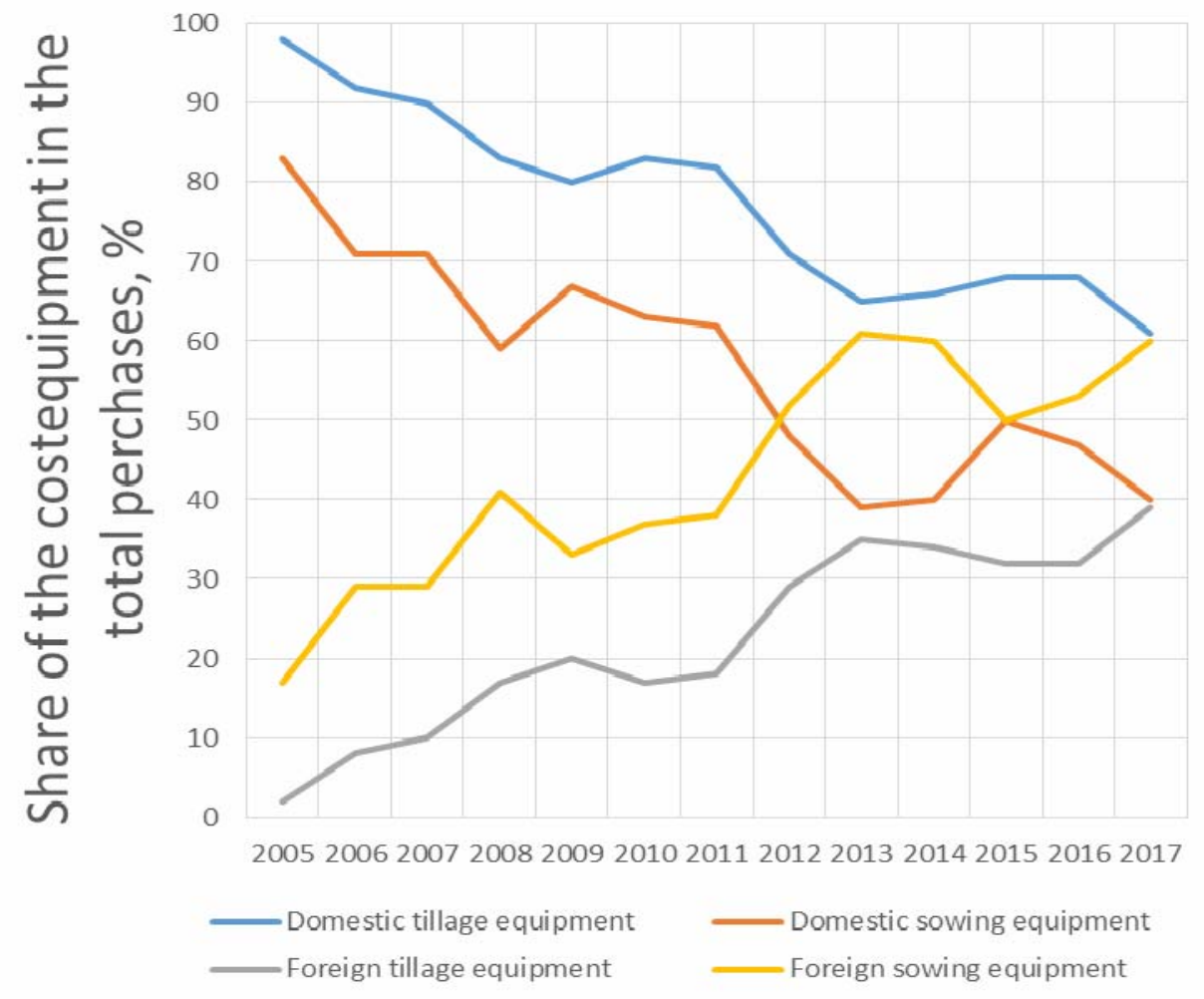

Fig.12. The structure of the domestic market agricultural machinery for years 


\section{Conclusions}

On the basis of the new knowledge obtained, highly effective technical means are developed that are characterized by high technical and economic indicators, namely: productivity is not lower than in the best world analogs, and in some technical means it exceeds 1,5-2,0 times, provide reduction of the total specific energy consumption by $20-30 \%$, at a price that is lower than $1,5-2,3$ times. The introduction of the production of these complexes has had an economic effect, which is about 2.5 milliard UAH.

On the basis of scientific knowledge on the interaction of working bodies of machines with soil and technological materials, requirements of agricultural technology to the quality and timing of technological operations, a set highly effective technical means that ensure the cultivation of grain and other crops for

energy- saving resource technologies.

\section{References}

1. Adamchuk V.V., Sydorchuk O.V., Lub P.M. et al. (2014). Planuvannia proektiv vyroshchuvannia silskohospodarskykh kultur na osnovi statystychnoho imitatsiinoho modeliuvannia: monohrafiia. [Planning of agricultural crop projects on the basis of statistical simulation: monograph]. Hlevakha: Vydavets PP Lysenko M.M. 224 p. [In Ukrainian].

2. Adamchuk V.V., Hrytsyshyn M.I. (Eds.). (2012). Systema tekhniko-tekhnolohichnoho zabezpechennia vyrobnytstva produktsii roslynnytstva. [System of technical and technological support of production of crop production]. Kyiv: Ahrarna nauka. 412 p. [In Ukrainian].

3. Adamchuk V.V. (2010). Teoriya tsentrobezhnykh rabochikh organov mashin dlya vneseniya mineral'nykh udobreniy: monografiya. [Theory of centrifugal working bodies of machines for mineral fertilizers: a monograph]. Kyiv: Ahrarna nauka. 178 p. [In Russian].

4. Adamchuk V., Beloev H., Bulgakov V., Korenko M. (2017). Mineral Fertilisation Theory and Working Tools of Fertiliser Spreading Machines. Sofia: Prof. Marin Drivon Publishing House of Bulgarian Academy of Sciences, P. 164.

5. Adamchuk V.V., Nasonov V.A., Bulhakov V.M. et al. (Adamchuk V.V. Ed.). (2016). Rozroblennia i vprovadzhennia $\mathrm{v}$ ahropromyslove vyrobnytstvo kompleksiv tekhnichnykh zasobiv dlia vyroshchuvannia zernovykh ta inshykh kultur za enerho-, resursooshchadnymy tekhnolohiiamy: monohrafiia. [Development and introduction into agroindustrial production of complexes of technical means for cultivating grain and other crops for energy, resource-saving technologies: monograph]. Kyiv: Ahrarna nauka. 368 p. [In Ukrainian].

6. Adamchuk V.V., Petrychenko Ye.A. (2015). Teoriia rukhu prychipnoho kombinovanoho posivnoho ahrehatu. [The theory of motion of a trailed combined sowing unit]. Visnyk KhNTUSH. Problemy nadiinosti mashyn ta zasobiv mekhanizatsii silskohospodarskoho vyrobnytstva. Vyp. 163. Kharkiv. P. 195 - 212. [In Ukrainian].

7. Bulgakov V., Adamchuk V., Arak M. et al. (2017). Theoretical research into the motion of combined fertilising and sowing tractor-implement unit. Agronomy Research. No 15(4). P. $1498-1516$.

8. Adamchuk V., Hovorov O., Petrychenko Ye. (2015). Strichkove vnesennia tverdykh mineralnykh dobryv. [Strapping of solid mineral fertilizers]. Propozytsiia. No 4. P. 136 - 137. [In Ukrainian].

9. Ratushnyi V.V. (2017). Teoretychne obgruntuvannia formy tvirnoi poverkhni obertovoho robochoho orhanu universalnoho protruiuvacha nasinnia. [Theoretical substantiation of the form of the creature surface of the rotating working organ of the universal seed purifier]. Mekhanizatsiia ta elektryfikatsiia silskoho hospodarstva: zahalnoderzhavnyi zb. NNTs «IMESH». Hlevakha, Vyp. No 5 (104). P. 68 - 75. [In Ukrainian].

10. Ratushnyi V.V. (2017). Doslidzhennia parametriv plivky robochoi ridyny na poverkhni obertovoho orhanu universalnoho protruiuvacha nasinnia. [Study of the parameters of the working fluid film on the surface of the rotating body of the universal seed purifier]. Mekhanizatsiia ta elektryfikatsiia silskoho hospodarstva: zahalnoderzhavnyi zb. NNTs «IMESH». Hlevakha. Vyp. No 6 (105). P. 65 - 73. [In Ukrainian].

11. Ratushnyi V.V. (2018). Vysokoiakisne protruiuvannia nasinnia. [High-quality seed dressing]. Ahrarnyi tyzhden. Ukraina. No 6 (330). P. 36 - 37. [In Ukrainian]. 